\title{
SEASONAL SCREENING OF THE MYCOTIC INFECTIONS OF CUL- TURED FRESHWATER FISHES IN KAFR EL-SHEIKH GOVERNORATE
}

\author{
Nadia B. Mahfouz ${ }^{1}$, Eman M. Moustafa ${ }^{1 *}$, Mohamed Kassab², Wesam H. Marzouk ${ }^{3}$
}

${ }^{1}$ Department of Fish Diseases and Management, Faculty of Veterinary Medicine, Kafrelsheikh University, Egypt, 'Department of of Cytology and Histology, Faculty of Veterinary Medicine, Kafrelsheikh University, ${ }^{3}$ Food safety specialist in Directorate of Health in Gharbia, Egypt

${ }^{*}$ Corresponding author, E-mail: emantarek2002@yahoo.com

\begin{abstract}
The present study was carried out to screen the predominant mycotic infections among freshwater fishes (Oreochromis niloticus and Clarias gariepinus) in Kafrelsheikh fish farms; with special focus on the seasonal incidence; as well as, the histopathological changes induced by the detected fungi. 500 specimens of freshwater fishes (400 0 . niloticus and 100 C. gariepinus) were investigated for seasonal incidence of mycotic diseases. Mycological examination revealed the isolation of 2148 fungal isolates from 375 diseased and 125 apparently healthy fish samples (1828 mould and 320 yeast isolates), of which 1258 were isolated from O. niloticus and 890 isolates from C. gariepinus. Saprolegnia was the predominant among diseased fishes with highest prevalence in late autumn $(10.68 \%, 6.96 \%)$ and winter $(6.81 \%, 7.87 \%)$ in 0 . niloticus and C. gariepinus, respectively. However, Pencillium sp. and Aspergillus sp. were the most predominant fungi isolated from apparently healthy fishes. The highest prevalence of Pencillium sp. were recorded in winter, whileas Aspergillus showed variations between species; Aspergillus flavus, Aspergillus niger were more prevalent in summer $(25.44 \%, 23.22 \%)$ and $(26.9 \%$, $37.44 \%$ ) and Aspergillus terrus, Aspergillus fumigatus were more prevalent in autumn $(5.98 \%, 5.67 \%)$ and $(7.69 \%, 8.23 \%)$ in 0 . niloticus and C. gariepinus, respectively. Moreover, the highest prevalence of Fusarium species was recorded in spring $(11.8 \%$, $5.91 \%$ ) from O. niloticus, C. gariepinus, respectively. Mucor recorded the highest prevalence in autumn (20.09\%) in O. niloticus and winter $(29.21 \%)$ in C. gariepinus; whileas Rhizopus was highest in summer $(7.89 \%, 5.21 \%)$ in $O$. niloticus and $C$. gariepinus, respectively. Four genera from yeast were isolated; Candida sp. (28.44\%, 36.27\%), Rhodotorula sp. (36.24\%, 24.51\%), Cryptococcus sp. (16.97\%, 20.59\%) and Trichosporon Sp. (18.35\%, 18.63\%) in O. niloticus and C. gariepinus, respectively. The histopathological findings revealed severe degenerative changes in skin and gills with presence of fungal hyphae and spores.
\end{abstract}

Key words: Clarias gariepinus; moulds; mycotic diseases; Oreochromis niloticus; yeast

\section{Introduction}

Fish serves as an important source of human dietary protein worldwide, especially in Afri- 
can countries (1). To compensate animal protein deficiency resulting from the increased interest for fish as human nourishment, fish farming is rapidly extending all over the world (2). In Egypt, the aquaculture industry provides about $77 \%$ of the total national fish production $(3,4)$.

Nile Tilapia (O. niloticus) is viewed as a standout amongst the most prevalent freshwater fishes in Egypt. It is widely cultured because of its palatability, cheap price, high growth rate, capacity to withstand pressure and infections, ability to spawn effectively and the minimal prerequisites with regard to management and energy inputs (5).

With expanding freshwater fish production movement around the world for farming, alongside enhanced ecological observing of fungal and fungal-like infections that are full degree of the effect of these pathogens on wild fish populations will soon rise as a noteworthy danger to freshwater biodiversity (6).

Serious aquaculture conditions can advance the transmission of fish diseases, particularly contagious fungal sicknesses, causing economic losses. Fungal infections are one of the primary drivers for mortalities and extraordinary financial misfortunes in cultured fishes. (7). The significance of fungal diseases in freshwater fish not halted just for frequency of mortalities but rather additionally as financial significance, such as decline growth rate, hatchability in choronic infection or by mycotoxins production by tainted organism in case of bad stockpiling feed. Fungal infections in fish are viewed as auxiliary to some other pathogen, water quality issues, poor conditions, injury (unpleasant taking care of or hostility), bacterial disease and/or parasites (8). Numerous fungi influencing fishes are considered opportunistic, assaulting the fishes only if they are stressed or immune-compromised as a result of troublesome natural conditions, or optional to bacterial or viral diseases, or when they have lost their bodily mucus protection due to trauma or excessive handling (9). Disregarding the fungal infections significance our insight about them is still poor for two fundamental reasons: difficult distinguishing proof of pathogenic fungi and the productive development of saprophytic fungi once the fish is dead (10).

Fungi is mostly attacked due to temperature change and bad water conditions which allow excessive zoospores to grow and the ammonia which is formed by rottening of fish waste wears away the mucus that protects the skin (11). Moreover, fungi can assault fishes of all the ages and it can also forestall fruitful hatching when it invades fish eggs (12). The most widely recognized fungal infection was saprolegniosis which is the real oceanic mycotic winter freshwater fish disease, frequently impacts wild and cultured fishes (13). Saprolegnia sp. taints the fishes because of sudden drop of water temperature and was regularly influencing fishes exhibiting fungal skin lesions which, unmistakable as cottony-white development on the epidermis of the influenced fishes (14). Aspergillus $s p$. causes systematic diseases with high death rates in fish, whereby the infections mostly occur through contamination of fish feed (15) and the pathogenesis of Aspergillus fumigatus and Aspergillus niger had been accounted in fresh water fishes by Chauhan (16).

The current study was carried out to screen the predominant mycotic infections with special focus on the seasonal incidence among freshwater fishes (O. niloticus and C. gariepi$n u s$ ) in Kafrelsheikh fish farms; as well as, detect the histopathological changes induced by the detected fungi.

\section{Materials and methods}

\section{A-Materials}

\section{Fish}

A total number of 500 examined cultured freshwater fishes; 400 O. niloticus and $100 \mathrm{C}$. gariepinus, were collected alive from different freshwater fish farms at Kafr El Sheikh Governorates along the four seasons of the year 2017. The samples were collected with an average body weight of $(40 \pm 5 \& 150 \pm 10 \mathrm{gm})$ for $O$. niloticus and C. gariepinus, respectively.

The alive collected fishes were transferred to the wet lab., Fish Diseases and Management Department, Faculty of Veterinary Medicine, Kafr El-Sheikh University, Egypt, held in well- 
prepared glass aquaria supplied with sufficient amounts of dechlorinated water with continuous aeriation (17).

\section{B-Methods}

\section{Clinical examination}

The collected fish were examined clinically according to the methods described by McVicar (18) to detect any external changes or clinical abnormalities.

\section{Postmortem examination}

Postmortem examination of the internal organs was carried out on sacrificed and freshly dead fish according to Austin \& Austin (19).

\section{Mycological examination}

\section{A. Isolation of the fungus from diseased fishes}

Mycological examination was done according to (18). Samples were taken from fish showing skin lesions using sterile dissecting needle from the skin, gills and internal organs (liver, kidney). Gathered specimens were inoculated into duplicate plates of SDA media with $500 \mathrm{mg}$ of cyclohexamid and $50 \mathrm{mg}$ of chloramphenicol dissolved in $3 \mathrm{ml}$ ethanol $95 \%$ were added to the media after autoclaving. The inoculated plates were incubated at $25^{\circ} \mathrm{C}-30^{\circ} \mathrm{C}$. For $3-5$ days (20). Negative plates were not disposed before 2 weeks (21). All the positive moulds cultures examined for gross and micro morphological characteristics (22).

\section{B. Identification of different fungi}

\section{B.1.Identification of moulds}

Recognization of moulds was completed according to Refai (23). Preliminary recognization utilizing wet mount preparation of fish samples made in $10 \% \mathrm{KOH}$. The confirmatory test of identification was carried out using souletip technique (24). Slide culture technique was carried out on those isolates whose identification was inconclusive after staining with lactophenol cotton blue (25).

\section{B. 2. Identification of yeast}

Plates of suspected specimens were analyzed microscopically for the presence of chlamydospores, arthrospores and blastospores $(20,23)$ and the plan of recognizable proof of yeasts given by Terrence (26). Rice agar media was used for identification of yeasts especillay Candida albicans by production of characteristic chlamydospores (23). The confirmatory distinguishing proof was carried out by germ tube test (27). Biochemical reaction using urease test was also conducted (28).

\section{Histopathological Examination}

Tissue specimens from the skin, gills and kidney of the infected fish samples were taken for histopathological examination (29).

\section{Results and Discussion}

The present work was applied to investigate the seasonal incidence of mycotic diseases among some freshwater fishes (O. niloticus \& C. gariepinus) in Kafrelsheikh Governorate.

\section{Clinical examination}

The external gross lesions of the examined O. niloticus revealed darkened skin, pale body coloration, scale detachment, fins erosion, and eye opacity as shown in (Plate 1: Fig. 1,2). These results agree with $(24,30)$. However, in fish naturally infected with Saprolegnia, there was scattered grayish white cotton wool-like growth on various parts of the body as well as presence of ulcerative areas in some cases as shown in (Plate 1: Fig. 3, 4); with unilateral eye cloudiness or opacity (Plate 1: Fig. 5); the result is in accordance with that of El-Atta, (31).

Fish death may be due to either blindness which consequently disable fish to feed or due to the fungal growth over gills causing suffocation. The ulcerative areas over the skin may be attributed to the lytic action of primary bacterial infection as all fungal infections are considered as secondary invader pathogen; these results agreed with many authors $(8,23,32-36)$.

On the other side, the infected $C$. gariepinus showed skin ulceration and scattered hemorrhagic patches on the ventral abdomen and mouth (Plate 1: Fig. 6). These symptoms may be attributed to the toxins secreted by moulds and yeasts causing severe symptomatic changes that appear on the fish in the form of haemorrhagic patches, ascitis and destruction and degeneration of the gills; the result agreed with $(16,24)$. 


\section{P.M. lesions}

The main observed postmortem lesions were liver enlargement with moderate petechial hemorrhage (Plate 1: Fig. 6\& 7). This result may support that the saprolegnia is a secondary invader following systemic bacterial infection which is responsible mainly for this internal lesions due to toxins produced by fungi and yeasts that interfere with function of liver causing congestion in internal organs especially liver $(2,31)$.

\section{Mycological examination}

Mycological examination revealed the isolation of 2148 fungal isolates from 375 diseased and 125 apparently healthy freshwater fish samples; 1258 fungal isolates from $O$. niloticus and 890 isolates from C. gariepinus (from skin, gills, liver and kidney). Recognizable proof of fungi into mould and yeast revealed that the incidence of mould and yeast was marginally higher in $O$. niloticus $(56.89 \%, 68.12 \%)$ in contrast with that in C. gariepinus (43.11\%, $33.88 \%$ ). The high frequency of mould isolates in $O$. niloticus agree with some authors $(9,24)$ and disagree with the incidence in $C$. gariepinus; as both of the two authors recorded high incidence of yeast isolates from catfish. This might be attributed to variable host susceptibility due to geographical distribution.

\section{Morphological identification of isolated moulds}

The colonies of Saprolgnia sp. appeared as white cotton-wool like growth on the petri dish (Plate 2: Fig. A) while, microscopically appeared as long, branched, un-septated hyphae (Plate 2: Fig. B, C). This result is in accordance with some reports $(8,31)$.

Pencillium sp. Colonies were white and fluffy then, turned into greenish blue in colour (Plate 2: Fig D), while microscopically, there were septated hyphe with un branched condiophores possessing metule with flask- shaped strigmata forming brush appearance. (Plate 2: Fig E, F). Nonetheless, Fusarium sp. Colonies were cottony or wooly in texture, snow white, pink-violet or blushing red in shading, with dis- semination of hued colors into the switch reverse surface of the medium (Plate 2: Fig G) and microscopically, they seemed long, extended and septated hyphae from which short conidiophores climbed and sometimes branched. Two kinds of conidia were watched, a huge banana shaped, septated macroconidia and a little, round, non septated microconidia. (Plate 2: Fig H). These results are in accordance with some authors $(9,37)$.

On the other side, Aspergillus sp. demonstrated few varieties within the same genus. $A$. flavus seemed smooth with various aerial growths; the shading changes from yellow to yellowish green by aging (Plate 2: Fig I), and microscopically the conidiophores were long and thick, the vesicles were globose and the strigmata were biseriate and radiate (Plate 2: Fig J). Colonies of $A$. niger had black color with radiated edges with wooly texture (Plate 2: Fig $\mathrm{K})$, while microscopically had extremely long, smooth and the strigmata were biseriate, minimized and radiate and the conidia were globes and smooth (Plate 2: Fig L). Colonies of A. terrus were velvety cinnamon buff to dark brown (Plate 2: Fig M), and microscopically, little hemispherical vesicle with long and smooth conidiophore (Plate 2: Fig N). Colonies of $A$. $f u$ migatus have unmistakable edge with a few shades of green, surface has a powder appearance with a white overskirt was seen at the edge in the zone of dynamic development (Plate 2: Fig O), and microscopically portrayed by hyaline and particularly septated hyphae, conidiophores were long with club-molded vesicle, round conidia were conceived from single row of strigmata (Plate 2: Fig P). These results agree with some authors $(9,37)$.

Colonies of Mucor sp. appeared fast-growing, white-to-gray cotton candy, became dark with time and fills the petri dish with fluffy mycelium and microscopically, non-septate broad hyphae, Sporangiophores are long, might be expanded and end with bear terminal round sporangia. The spores scattered and no rhizoids are formed. Rhizopus sp. colonies were deeply cottony; white turned to gray-brown on surface with aging. Microscopically, broad hyphae 
could be observed, Sporangiophores are unbranched and connect to each another by septated hyphae, large sac-like sporangia that contain sporangiospores. These results agree with some authors $(9,37)$.

\section{Morphological identification of yeast iso- lates}

The isolates were cultivated on Rice agar media after culturing on SDA. In the current study, four genera were identified (Candida, Rhodotorula, Trichosporon and Cryptococcus). All genera reacted positively with urease test except Candida. Rhodotorula sp. was identified on SDA by formation of carotenoid pigments; that vary from orange to red (light pink flat colonies). Microscopically, revealed budding of round, oval large cells when stained with Gram's stain. On Rice agar media, showed large round blasto-conidia with absence of pseudohyphae. Cryptococcus $s p$. appeared rapidly on SDA as flat or slightly heaped shiny moist mucoid colonies with smooth edges. Its color changed from creamy at first to brown later. Microscopically, the colonies were ovoid, spherical with thick wall and mostly showed capsule with budding. On Rice agar media, no pseudo-hyphae but appeared as budding cells. Trichosporon $s p$. appeared on SDA firstly as smooth flat, or wrinkled white to creamy colonies that turned waxy with central folds surrounded by wrinkled furrows. Microscopically, appearance of hyaline mycelium which is separated and fragmented into rectangular arthrospores. On Rice agar media, Trichosporon sp. appeared as septated hyphae, pseudohyphae and arthrospores. Candida species colonies on SDA appeared creamy colored pasty colonies within 48-72hrs. On Rice agar media, C. albicans showed terminal chlamydospores, blastocondia and pseudo-hyphae. Other Candida sp. fails to produce pseudohyphae. This result is in accordance with some authors (9, 37-39).

Incidences of moulds and yeast among different seasons and different organs

As shown in table ( $1 \& 2$ ), mycological examination of $400 \mathrm{O}$. niloticus and $100 \mathrm{C}$. gariepinus revealed an incidence of several moulds including Saprolegnia sp. $(53,32)$ isolates, Penicillium sp. (152, 131), Fusarium sp. (78, 38) A. flavus (233, 149), A. niger (247, 223), A. terreus $(35,22)$, A. fumigatus $(29,15)$ Mucor $(148,136)$ and Rhizopus $(65,42)$ in $O$. niloticus and C. gariepinus, respectively.

Saprolegnia sp. showed the highest prevalence in late autumn $(10.68 \%, 6.96 \%)$ and winter $(6.8 \%, 7.8 \%)$ in $O$. niloticus and C. gariepinus, respectively. This may be attributed to that seasonal variation play an important role in spreading of the Saprolegnia infection among freshwater fishes where the water temperature was low. These results agree with some authors $(9,24,37)$ where they mentioned that saprolegniasis occurred during the winter season and colder months of the year. The highest incidence within organs was observed to be from the skin and fins $(77.4 \%, 65.63 \%)$ followed by the gills $(22.6 \%, 34.4 \%)$ in $O$. niloticus and $C$. gariepinus, respectively but, not isolated from liver and/or kidney. The results are in accordance with those of many authors $(8,9,14,30$, $31)$ as shown in table (2).

Pencillium sp. was isolated with the highest prevalence in winter $(18.98 \%$ \& $23.22 \%)$ from O. niloticus, C. gariepinus respectively. The highest incidence within organs was observed to be from the skin and fins $(36.2 \%, 47.3 \%)$ followed by gills $(30.9 \%, 20.6 \%)$ in $O$. niloticus and $C$. gariepinus, respectively. These results are similar to those reported by Ali, (37). Besides, Penicillum sp. could be isolated also from liver $(22.4 \%, 13.7 \%)$ and kidney $(10.5 \%$, $18.3 \%)$. These results agree with some authors $(9,30)$. Different species of Pencillium were isolated with high incidence from apparently healthy fishes rather than diseased one, therefore members of this genus can be considered as saprophytes $(9,37)$.

Fusarium sp. was isolated with the highest prevalence in spring $(11.8 \%, 5.91 \%)$ from $O$. niloticus, C. gariepinus respectively. The highest incidence within organs was observed to be in gills $(37.18 \%, 34.2 \%)$ in $O$. niloticus and $C$. gariepinus, respectively. This might be attributed to the high affinity of fungal spores to high oxygen tension (37). It could be isolated from skin, fins, liver and kidney as well. 
Aspergillus sp. showed some variation according to species. A. flavus was recorded all over the year and more prevalent during hot weather with high incidence during summer $(25.44 \%, 23.22 \%)$ followed by spring $(16.24 \%$, $22.08 \%$ ) in $O$. niloticus, $C$. gariepinus. The result is similar to some previous papers $(9,37$, 40). A. niger was more prevalent during hot weather with high incidence during summer $(26.9 \%, 37.44 \%)$ in $O$. niloticus, C. gariepinus, respectively. These results are similar to some previous papers $(9,37,40)$. A. terrus was more prevalent during autumn $(5.98 \%, 5.69 \%)$ in $O$. niloticus and $C$. gariepinus, respectively. These results are similar to some previous papers $(9$, 37, 40). A. fumigatus was more prevalent during autumn $(7.69 \%, 8.23 \%)$ in $O$. niloticus, $C$. gariepinus. These results are similar to some previous papers $(9,37,40)$. In the current study, the highest incidence within organs was observed to be in liver in most of Asperigillus sp. This may support the fact that Asperigillosis is a systemic disease.

Zygomycetes (Mucor and Rhizopus) are the most common fungi isolated from apparently healthy fish and diseased $O$. niloticus and $C$. gariepinus with high incidence during autumn season and these results agree with Ali, (37). Mucor species were isolated with the highest prevalence in autumn (20.09\%) from O. niloticus and winter (29.21\%) from C. gariepinus, respectively. The highest incidence within organs was observed to be from the skin and fins $(45.3 \%, 46.3 \%)$ followed by gills $(29.7 \%$, $27.9 \%$ ) in $O$. niloticus and $C$. gariepinus, respectively. The result is similar to those reported by Ali (37). It could be isolated also from liver $(15.5 \%, 16.9 \%)$ and kidney $(9.46 \%, 8.8 \%)$ in $O$. niloticus and C. gariepinus, respectively. These results agree with many authors $(9,37)$.

On the other side, Yeast isolates revealed 4 genera; Candida $(62,37)$, Rhodotorula $(79,52)$, Trichosporon (40, 19) and Cryptococcus (37,
21 ) isolated from $O$. niloticus and $C$. gariepi$n u s$, respectively. Yeast was also isolated with high frequency from diseased fishes rather than apparently healthy; these results came in agreement with those recorded (9). Candida sp. accounted for $(28.44 \%, 36.27 \%)$ of the isolates and Rhodotorula sp. $(36.24,24.51 \%)$ from $O$. niloticus and $C$. gariepinus. The current results came in agreement with those recorded by Tartor et al., (39). Samples collected from skin, gills, liver, and kidney revealed that $C$. albicans and Rhodotorula sp. were the highest yeast isolates. These findings were supported by the view reported by (9). Cryptococcus sp. in the present study was isolated with prevalence of (16.97\%, 20.59\%) from O. niloticus and $C$. gariepinus, respectively; nearly similar results were recorded by (38) but disagree with Tartor et al., (39). Trichosporon sp. was detected to be $(18.35 \%, 18.63 \%)$ from $O$. niloticus and $C$. gariepinus, respectively; nearly similar results were recorded by $(24,38)$ but disagree with Tartor et al., (39).

\section{Histopathological findings}

Histopatholgical examination of naturally infected O. niloticus with Saprolrgnia sp. revealed severe degenerative changes in the skin. Necrosis of dermis and hypodermis, the underling dermis was edematous with degenerative changes of muscle fibers containing fragments from the fungal hyphae (Plate 3: Fig. A). Ulceration, loss of epidermis and loss of texture of scales and sometimes ulcer can be observed (Plate 3: Fig. B, C). Gills showed severe hyperplasia and hypertrophy of the epithelial lining of secondary lamellae with congestion of branchial blood vessels (Plate 3: Fig. D, E). Kidney revealed necrosis in some tubules together with peritubular fibrosis (Plate 3: Fig. F). These results agreed with many authors $(11,31,34)$. 
Table 1: Seasonal Prevalence of Mould and yeast in $O$. niloticus and C. gariepinus

\begin{tabular}{|c|c|c|c|c|c|c|c|c|c|c|c|c|c|c|c|c|}
\hline & \multicolumn{8}{|c|}{ Oreochromis niloticus (100 fish/season) } & \multicolumn{8}{|c|}{ Clarias garipinus (25 fish/season) } \\
\hline & \multicolumn{2}{|c|}{ Winter } & \multicolumn{2}{|c|}{ Spring } & \multicolumn{2}{|c|}{ Summer } & \multicolumn{2}{|c|}{ Autumn } & \multicolumn{2}{|c|}{ Winter } & \multicolumn{2}{|c|}{ Spring } & \multicolumn{2}{|c|}{ Summer } & \multicolumn{2}{|c|}{ Autumn } \\
\hline & No. & $\%$ & No. & $\%$ & No. & $\%$ & No. & $\%$ & No. & $\%$ & No. & $\%$ & No. & $\%$ & No. & $\%$ \\
\hline \multicolumn{17}{|l|}{ Mould } \\
\hline Saprolegnia & 28 & 6.81 & 0 & 0 & 0 & 0 & 25 & 10.68 & 21 & 7.87 & 0 & 0 & 0 & 0 & 11 & 6.96 \\
\hline Pencillium & 78 & 18.98 & 11 & 4.06 & 39 & 11.40 & 24 & 10.26 & 62 & 23.22 & 29 & 11.42 & 23 & 10.90 & 17 & 10.76 \\
\hline Fusrium & 17 & 4.14 & 32 & 11.81 & 20 & 5.85 & 9 & 3.85 & 8 & 2.99 & 15 & 5.91 & 10 & 4.74 & 5 & 3.16 \\
\hline Asp.flavus & 65 & 15.82 & 44 & 16.24 & 87 & 25.44 & 37 & 15.81 & 10 & 3.75 & 56 & 22.05 & 49 & 23.22 & 34 & 21.52 \\
\hline Asp.Niger & 83 & 20.19 & 50 & 18.45 & 92 & 26.90 & 22 & 9.40 & 37 & 13.86 & 82 & 32.28 & 79 & 37.44 & 25 & 15.82 \\
\hline $\begin{array}{l}\text { Asp.Fu- } \\
\text { migtus }\end{array}$ & 0 & 0 & 0 & 0 & 11 & 3.22 & 18 & 7.69 & 0 & 0 & 0 & 0 & 9 & 4.27 & 13 & 8.23 \\
\hline Asp.terrus & 7 & 1.70 & 10 & 3.69 & 4 & 1.17 & 14 & 5.98 & 0 & 0 & 6 & 2.36 & 0 & 0 & 9 & 5.67 \\
\hline Mucor sp & 62 & 15.09 & 12 & 4.43 & 27 & 7.89 & 47 & 20.09 & 78 & 29.21 & 27 & 10.63 & 6 & 2.84 & 25 & 15.82 \\
\hline Rhizopus sp & 19 & 4.62 & 6 & 2.21 & 27 & 7.89 & 13 & 5.56 & 17 & 6.37 & 5 & 1.97 & 11 & 5.21 & 9 & 5.67 \\
\hline $\begin{array}{l}\text { Yeast } \\
\quad \text { Rhodotorulla } \\
s p\end{array}$ & 26 & 6.33 & 30 & 11.07 & 6 & 1.75 & 17 & 7.26 & 7 & 2.62 & 9 & 3.54 & 5 & 2.37 & 4 & 2.53 \\
\hline Candida sp & 10 & 2.43 & 25 & 9.23 & 19 & 5.56 & 8 & 3.42 & 13 & 4.87 & 8 & 3.15 & 12 & 5.69 & 6 & 3.80 \\
\hline $\begin{array}{l}\text { Tricho- } \\
\text { sporon sp }\end{array}$ & 7 & 1.70 & 20 & 7.38 & 10 & 2.92 & 0 & 0 & 3 & 1.12 & 9 & 3.54 & 7 & 3.32 & 0 & 0 \\
\hline $\begin{array}{l}\text { Cryptococ- } \\
\text { cus sp }\end{array}$ & 9 & 2.19 & 31 & 11.44 & 0 & 0 & 0 & 0 & 11 & 4.12 & 8 & 3.15 & 0 & 0 & 0 & 0 \\
\hline \multirow[t]{2}{*}{ Total } & No. & $\%$ & No. & $\%$ & No. & $\%$ & No. & $\%$ & No. & $\%$ & No. & $\%$ & No. & $\%$ & No. & $\%$ \\
\hline & 411 & 32.67 & 271 & 21.54 & 342 & 27.19 & 234 & 18.60 & 267 & 30 & 254 & 28.54 & 211 & 23.71 & 158 & 17.75 \\
\hline $\begin{array}{l}\text { Total No. of } \\
\text { isolates }\end{array}$ & \multicolumn{8}{|c|}{1258} & \multicolumn{8}{|c|}{890} \\
\hline
\end{tabular}

Table 2: Incidence of Mould and yeast in organs of $O$. niloticus and C. gariepinus

\begin{tabular}{|c|c|c|c|c|c|c|c|c|c|c|c|c|c|c|c|c|c|c|}
\hline & \multirow[b]{3}{*}{ No. } & \multicolumn{8}{|c|}{ Oreochromis niloticus (100 fish/season) } & \multicolumn{9}{|c|}{ Clarias garipinus (25 fish/season) } \\
\hline & & \multicolumn{2}{|c|}{ Skin\&Fins } & \multicolumn{2}{|c|}{ Gills } & \multicolumn{2}{|c|}{ Liver } & \multicolumn{2}{|c|}{ Kidney } & \multirow[b]{2}{*}{ No. } & \multicolumn{2}{|c|}{ Skin\&Fins } & \multicolumn{2}{|c|}{ Gills } & \multicolumn{2}{|c|}{ Liver } & \multicolumn{2}{|c|}{ Kidney } \\
\hline & & No. & $\%$ & No. & $\%$ & No. & $\%$ & No. & $\%$ & & No. & $\%$ & No. & $\%$ & No. & $\%$ & No. & $\%$ \\
\hline \multicolumn{19}{|l|}{ Mould } \\
\hline Saprolegnia & 53 & 41 & 77.4 & 12 & 22.6 & 0 & 0 & 0 & 0 & 32 & 21 & 65.63 & 11 & 34.37 & 0 & 0 & 0 & 0 \\
\hline Pencillium & 152 & 55 & 36.2 & 47 & 30.9 & 34 & 22.4 & 16 & 10.5 & 131 & 62 & 47.4 & 27 & 20.6 & 18 & 13.7 & 24 & 18.3 \\
\hline Fusrium & 78 & 21 & 26.92 & 29 & 37.18 & 11 & 14.1 & 17 & 21.8 & 38 & 10 & 26.3 & 13 & 34.2 & 9 & 23.7 & 6 & 15.8 \\
\hline Asp.flavus & 233 & 83 & 35.6 & 47 & 20.20 & 78 & 33.5 & 25 & 10.7 & 149 & 33 & 22.1 & 62 & 41.6 & 30 & 20.1 & 24 & 16.1 \\
\hline Asp.Niger & 247 & 92 & 37.2 & 46 & 18.6 & 81 & 32.8 & 28 & 11.3 & 223 & 95 & 42.6 & 72 & 32.3 & 33 & 14.8 & 23 & 10.3 \\
\hline $\begin{array}{l}\text { Asp.Fu- } \\
\text { migtus }\end{array}$ & 29 & 10 & 34.48 & 12 & 41.40 & 3 & 10.34 & 4 & 13.8 & 15 & 10 & 66.7 & 5 & 33.3 & 0 & 0 & 0 & 0 \\
\hline Asp.terrus & 35 & 13 & 37.1 & 7 & 20 & 10 & 28.6 & 5 & 14.3 & 22 & 9 & 40.9 & 5 & 22.7 & 7 & 31.8 & 1 & 4.5 \\
\hline Mucor sp & 148 & 67 & 45.27 & 44 & 29.73 & 23 & 15.54 & 14 & 9.46 & 136 & 63 & 46.3 & 38 & 27.9 & 23 & 16.9 & 12 & 8.8 \\
\hline \multicolumn{18}{|l|}{ Yeast } & 0 \\
\hline $\begin{array}{l}\text { Rhodotorulla } \\
s p\end{array}$ & 79 & 25 & 31.6 & 40 & 50.6 & 4 & 5.1 & 10 & 12.7 & 25 & 7 & 28 & 2 & 8 & 12 & 48 & 4 & 16 \\
\hline Candida sp & 62 & 18 & 29 & 20 & 32.3 & 16 & 25.8 & 8 & 12.9 & 37 & 7 & 18.9 & 4 & 10.8 & 17 & 45.9 & 9 & 24.3 \\
\hline $\begin{array}{l}\text { Tricho- } \\
\text { sporon sp }\end{array}$ & 40 & 18 & 45 & 12 & 30 & 10 & 25 & 0 & 0 & 19 & 2 & 10.53 & 7 & 36.84 & 10 & 52.63 & 0 & 0 \\
\hline $\begin{array}{l}\text { Cryptococ- } \\
\text { cus sp }\end{array}$ & 37 & 0 & 0 & 25 & 67.57 & 12 & 32.43 & 0 & 0 & 21 & 0 & 0 & 13 & 61.9 & 6 & 28.6 & 2 & 9.5 \\
\hline Total & & $\begin{array}{l}\text { No. } \\
485\end{array}$ & $\begin{array}{l}\% \\
38.55\end{array}$ & $\begin{array}{l}\text { No. } \\
364\end{array}$ & $\begin{array}{l}\% \\
28.93\end{array}$ & $\begin{array}{l}\text { No. } \\
282\end{array}$ & $\begin{array}{l}\% \\
22.42\end{array}$ & $\begin{array}{l}\text { No. } \\
127\end{array}$ & $\begin{array}{l}\% \\
10.01\end{array}$ & & $\begin{array}{l}\text { No. } \\
349\end{array}$ & $\begin{array}{l}\% \\
39.21\end{array}$ & $\begin{array}{l}\text { No. } \\
271\end{array}$ & $\begin{array}{l}\% \\
30.45\end{array}$ & $\begin{array}{l}\text { No. } \\
165\end{array}$ & $\begin{array}{l}\% \\
18.54\end{array}$ & $\begin{array}{l}\text { No. } \\
105\end{array}$ & $\begin{array}{l}\% \\
11.79\end{array}$ \\
\hline \multicolumn{2}{|c|}{$\begin{array}{l}\text { Total No. of iso- } \\
\text { lates }\end{array}$} & \multicolumn{8}{|c|}{1258} & & & & & 890 & & & & \\
\hline
\end{tabular}



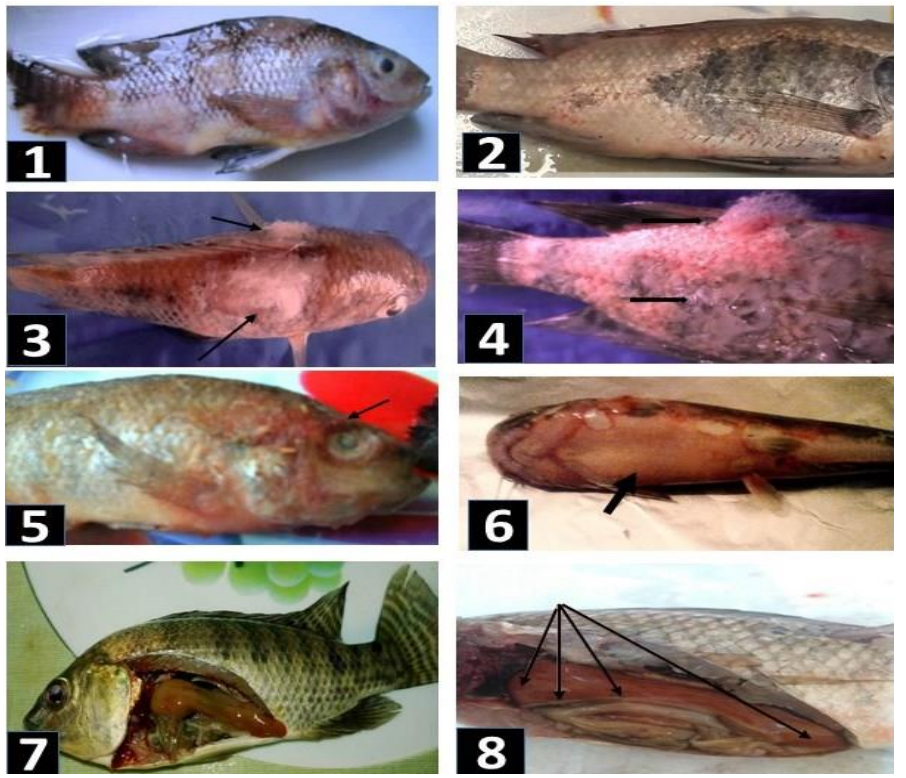

Plate 1: $(1,2)$ O. species showing skin darkening, scale detachment and erosion of membranous part of fins. $(3,4) O$. species showing cotton wool-like growth on various parts of the body ,ulceration of skin. (5) $O$. species showing cloudy and opaque eye. (6) $C$. gariepinus showing skin ulceration, scattered hemorrhagic patches on the ventral abdomen and mouth. (7) Naturally diseased O.niloticus showing moderate petechial hemorrhage, dark liver enlargement (8) A naturally examined $O$. niloticus showing threads of congestion along the surface of live
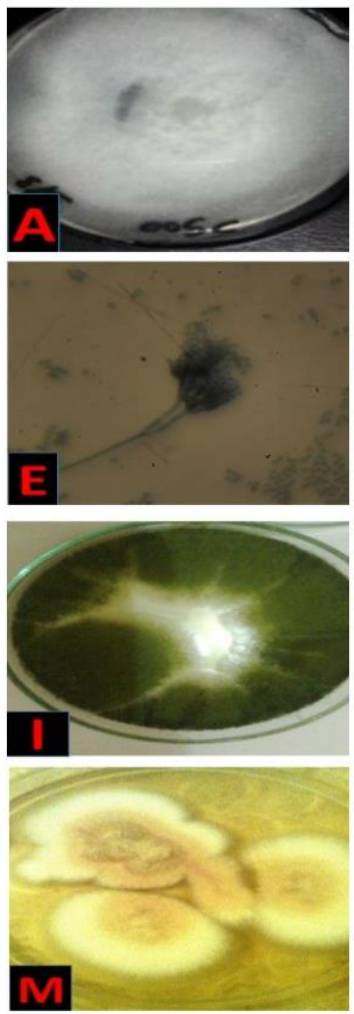
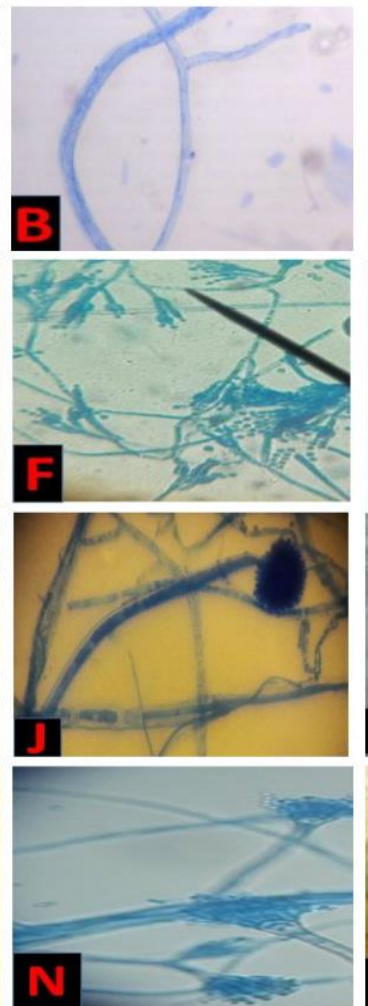
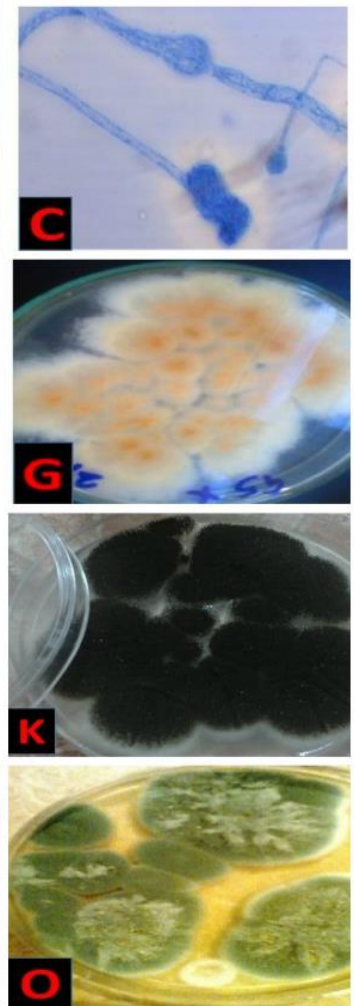
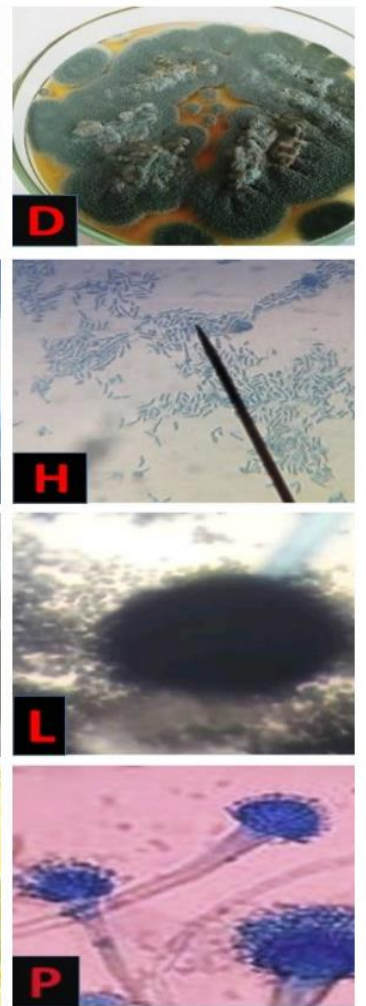

Plate 2: (A) Saprolegnia species with the characteristic cotton- wool like growth colony on SDA, (B, C) branched aseptic hyphe, (D, E) Penicillium sp. on SDA with different colour and texture, (E, F) Penicillium sp. showing brush- like arrangement, (G) a colony of Fusarium sp. on SDA with rose pigments on the center, (H) Fusarium under light microscope (I) A. flavus on SDA, (J) A. flavous showing characteristic typical head, (K) A colony of A. niger on SDA, (L) Aspergillus niger showing characteristic round head with black conidia, (M), Colonies of Aspergillus terreus on SDA, (N) A. terreus with small hemispherical vesicle, (O) A colony of A. fumigatus on SDA, (P) A. fumigatus with columnar head 

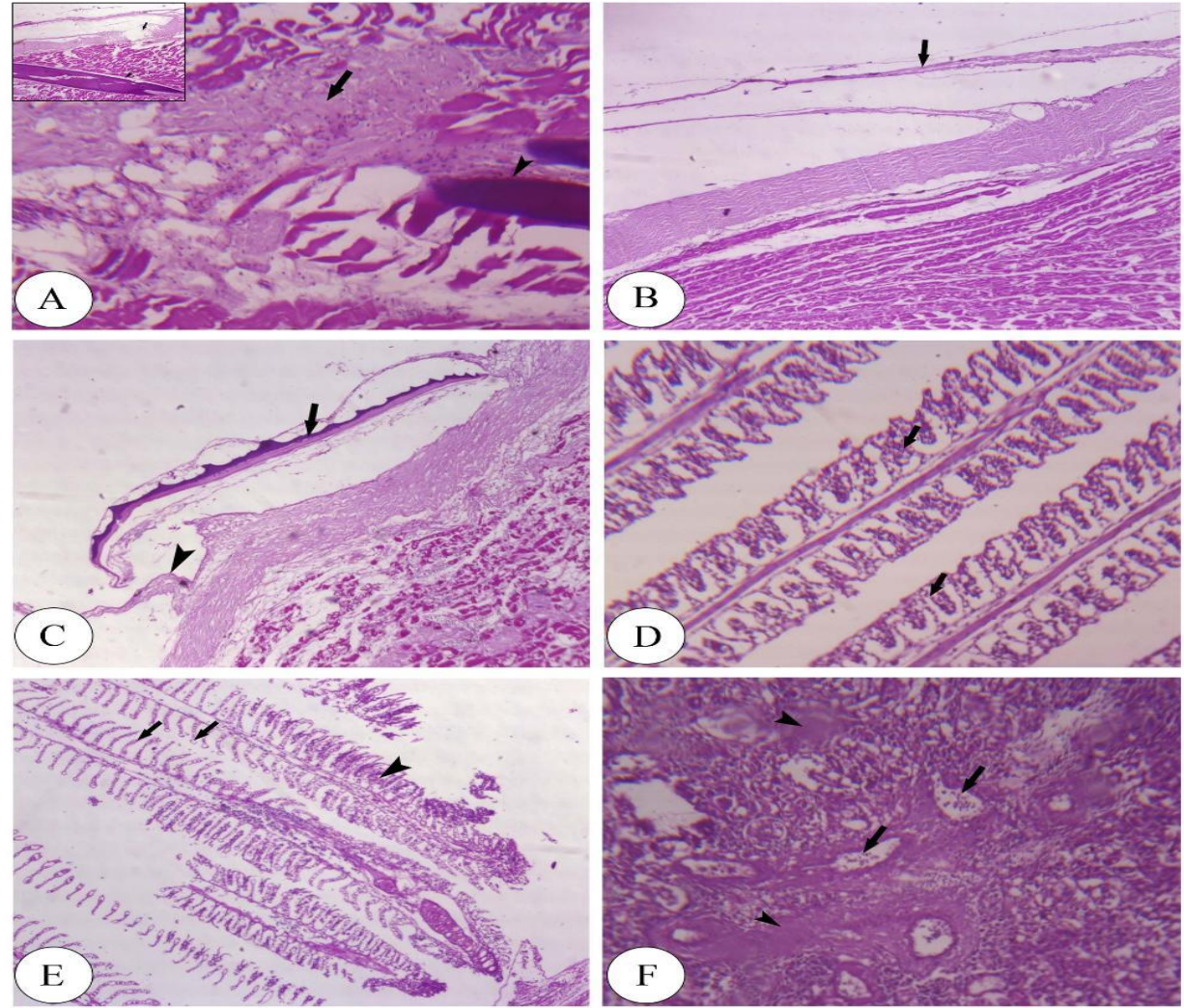

Plate 3: Photomicrograph of skin, gills and kidney of Oreochromis niloticus infected with Saprolegnia $s p$. (A) Necrosis of dermis, hypodermis, edema and degenerative changes of muscle fibers (Arrow) with presence of hyphae of saprolegnia (Arrow head) x 400. (B) Ulceration \& loss of epidermis and loss of texture of scales (Arrow). (C) Normal scale (Arrow) and Ulcer in neighboring (Arrow head). (D) Gills showing sever Hyperplasia \& Hypertrophy of the epithelial lining of secondary lamellae with fusion in neighboring (Arrow). (E) Infection of saprolegnia at the tip of primary lamellae with congestion of blood vessles and hyperplasia\& hypertrophy (Arrow head) while other part filament is normal (Arrow). (F) Infected kidney with peritubular fibrosis( Arrow) and necrosis in some tubule (Arrow head).

\section{Conclusion}

From the present study, it could be concluded that Saprolegnia was the predominant among diseased fishes with highest prevalence in late autumn $(10.68 \%, 6.96 \%)$ and winter $(6.8 \%, 7.8 \%)$ in $O$. niloticus and $C$. gariepinus, respectively. However, Pencillium sp. and Aspergillus $s p$. were the most predominant fungi isolated from apparently healthy fishes. The highest prevalence of Pencillium sp. were recorded in winter, whileas Aspergillus showed variations between species; A. flavus, A. niger were more prevalent in summer and A. terrus, A. fumigatus were more prevalent in autumn in $O$. niloticus and C. gariepinus, respectively.
Moreover, the highest prevalence of Fusarium species were recorded in spring from $O$. niloticus and C. gariepinus, respectively and Zygomycetes (Mucor and Rhizopus) recorded the highest prevalence in autumn in $O$. niloticus and winter in $C$. gariepinus. Four genera from yeast were isolated; Candida sp., Rhodotorula sp., Cryptococcus sp. and Trichosporon Sp. The histopathological findings revealed severe degenerative changes in skin and gills with presence of fungal hyphae and spores.

\section{Conflict of interest}

The authors declare that no conflict of interest. 


\section{References}

1. Hussain SM, Javed M, Javid A, Javid T, Hussain N. Growth responses of Catla catla, Labeo rohita and Cirrhina mrigala during chronic exposure of iron. Pak J Agric Sci. 2011;(1);48:225-30.

2. Mohamed HMA, Walaa FAE, Braeuning A, Hammad S. Detection of aflatoxin -producing fungi isolated from tilapia and fish feed. Excil $\mathbf{J}$. 2017; 16:1308-18.

3. El-Sayed AFM, Dickson MW, El-Naggar GO. Value chain analysis of the aquaculture feed sector in Egypt. Aquac 2015; 437: 92-101.

4. FAO. Fishery and Aquaculture Statistics Yearbook 2014. Rome, Italy: Food and Agriculture organization of the United Nations. ISSN 20706057 (2016).

5. Nandlal S, Pickering T. Tilapia fish farming in Pacific Island countries. Vol. 1: Tilapia hatchery operation. Noumea, New Caledonia: Secretariat of the Pacific Community, 2004.

6. Rodolphe EG, Marshall WL, Lilje O, Jessop CN, Gleason FH, Andreou D. Current ecological understanding of fungal-like pathogens of fish: what lies beneath?. HAL Id: hal-01321245 http://hal.upmc.fr/hal-01321245. 2014

7. Ashour AA, Mustafa SA, Yassein SN. Histopathological studies on common carp (Cyprinus carpio $L$.) infected with Saprolegnia sp. and treated with Virkon ${ }^{\circledR}$. Mirror Res. Vet. Sci. Anim. 2017; 6: 19-30.

8. Noor El-Deen A, Hussein M O, Zaki M $\mathrm{S}$ and Abo-State H A Mass Mortality in Cultured Nile Tilapia Oreochromis niloticus due to Saprolegniosis with Emphasis on Treatment Trials. J Biol Sci. 2018; 18(1):39-4

9. Refai MK, Laila K, Amany M, Shimaa ES. The assessment of Mycotic settlement of freshwater fishes in Egypt. J Am Sci, 2010; 6(11): 823-31.

10. Pickering AD, Willoughby LG. Saprolegnia infections of salmonid fish. In Microbial Diseases of Fish, Edit Roberts, RJ Academic Press, London, 1982, 271-98.

11. Chauhan R, Lone S, Beigh AH. Pathogencity of three species of Aspergullis (A. fumigatus, A. niger \& A. sydowii) on some freshwater Fishes. Life Sci Leaflets, 2014; 14:65-72. (Online print).

12. West PV. Saprolegnia paracitica, an oomycyte pathogen with a fishy appetite: New challenges for an old problem, mycologist, 2006: 20(3):99104.

13. Yanong RP. Fungal diseases of fish. Vet.
Clin. North Am. Exot. Anim. Pract. 2003; 6: $377-$ 400.

14. Eissa AE, Abdelsalam M, Tharwat N, Zaki M. Detection of Saprolegnia parasitica in eggs of angelfish Pterophyllum scalare (Cuvier-Valenciennes) with a history of decreased hatchability. Int. J. Vet. Sci. Med. 2013; 1: 7-14.

15. Urquhart K, Collins C, Monte M, Sokolowska J, Secombes C, Collet B. Individual measurement of gene expression in blood cells from Rainbow trout On- corhynchus mykiss (Walbaum). JEAAS. 2016; 2(1):1-9.

16. Chauhan R. Studies on conidial fungi isolated from some fresh water fishes. International journal of Advanced Life Sciences (IJALS), 2013; $6(4): 131-5$.

17. Innes WT. Exotic Aquarium Fishes, 19th edition. Aquarium Incorporated, New Jersey 1966; 1(12):24-25,29-30 and530-3

18. McVicar AH. Ichthyophonus infections of fish. In: Roberts RJ (ed) Microbial diseases of fish. Academic Press. London, 1982: 243-69.

19. Austin B, Austin DA. Bacterial fish pathogens; diseases of farmed and wild fish. Springer, New York, London). 2012.

20. Taha M. Medical mycology "Atlas of medically important \& dermatomycosis". 1st ed., Mecca printing house, Cairo, Egypt. 2011.

21. Feingold SM, Baron EJ. Bailey and Scoll's Diagnostic Microbiology. The Cv. Mosby co., St. Louis, 1986.

22. Ellis MB. Dematiaceous Hyphomycetes. Commonwealth Mycological Institute: Kew Surrey, UK, 1971.

23. Refai M. Isolation and Identification of fungi. Fac. Vet. Med. Cairo University. 1987

24. Diab AMA. Studies on the mycological affections in cultured fresh water fishes in KafrelSheikh governorate M.V.Sc Thesis (Fish diseases and management), Fac Vet. Med., Tanta University; 2006.

25. Domsch KH, Gams W, Anderson TH. Compendium of soil fungi. 2nd taxonomically revised edition by W. Gams. IHW, Eching. 2007.

26. Terrence CD. A practical approach to identification of yeast like organisms. Amer. Jour Microbiol 1971; 35(5):580-90.

27. Martin MV. Germ tube formation by oral strains of Candida albicans. J. Med. Microbiol. 1979; 12:187-193.

28. Cruickshank R, Duguid JP, Mariom BP, Swain RHA. Medical Microbiology the Practice of Medical Microbiology. $12^{\text {th }}$ Edn., Churchill Livingstone, London, New York. 1975. 
29. Bancroft JD, Gamble M. Techniques. 5th edition; Churchill Livingstone, London, UK., 2007: $125-38$.

30. Marzouk MS, Rezeka SM, El Gamal MH. Some mycological investigations on cultured tilapia in Kafr El Sheikh Governorate. Kafr El Sheikh Vet. Med. J., 2003; 1: 97-111.

31. El-Atta MEA. Saprolegniosis in freshwater cultured Tilapia nilotica (Oreochromis niloticus) and trial for control by using Bafry D50/500. Proceedings of the 8th International Symposium on Tilapia in Aquaculture, October 12-14, 2008, Cairo, Egypt, 2008: 1403-18

32. Bruno DW, Wood BP. Saprolegnia and other Oomycetes. In: Fish Disease and Disorder, Viral, Bacterial and Fungal Infections, Woo, P.T.K. and D.W. Bruno (Eds.)., CABI Publishing, Wallingford, Oxon, United Kingdom, 1994: 599-659.

33. Hussein MM, Hatai K. Saprolegnia salmonis sp. nov. isolated from sockeye salmon, Onchrhynchus nerka. Mycoscience, 1999; 40: 387-91.

34. El-Ashram AMM, Abd El-Rhman AM, Sakr SF. A contribution to saprolegniosis in cultured Nile tilapia (Oreochromis niloticus) with special reference to its control. Egypt J. Aquat. Biol. \& fish. 2007; 11(3):943-55.
35. Chauhan R. Studies on some fresh water fishes found infected with dermatomycoses, collected from different water bodies in and around Bhopal, India. Indo Am. J. Pharm. Res. 2014; 4: 1591-6.

36. Ganguly S, Wakchaure R, Praveen PK, Para PA. Fungal infections in fishes: A brief review. Int. J. Pharm. Life Sci., 2016; 7: 5245-6.

37. Ali ShELM. Studies on the causative agents of mycotic diseases in fresh water fishes. M.V.Sc Thesis (Microbiology), Fac Vet. Med., Cairo University. 2007.

38. Abbas MS, Khalaf JM, Yassein SN. Isolation and identification of systemic mycological isolates from fishes samples that obtained from local markets in Baghdad, Iraq. World J Exp Biosci 2016; 4: $143-6$.

39. Tartor Y, Taha M, Mahboub H, El Ghamery M. Yeast species associated with diseased fish: Occurrence, identification, experimental challenges and antifungal susceptibility testing. Aquac 2018;

40. Diab AMA. Studies on some systemic mycotic affection in cultured fresh water fish Ph.D Thesis (Fish diseases and hygiene), Fac Vet. Med. Alexandria university.2010. 